\title{
Embodying Compassion: Disability Sport and the Mercy of God
}

\author{
Brian Brock
}

10 March 2017

\begin{abstract}
:
This paper offers a robustly theological account of compassion, highlighting its bodily nature. Divine mercy is presented as being conveyed through human bodies to remake and enliven both the human agent and recipient. Culminating in a story of a physically and mentally impaired runner, this account of mercy and compassion fleshes out God's mercy can be understood as flowing through human bodies in the context of sporting activities. A challenge is thus levied at modern secularized accounts of compassion and mercy as well as many of the dominant values in contemporary sport — flawless athletic beauty, agonistic competition, and financial successwhich have rendered simple acts of inter-competitive compassion and mercy nearly unintelligible.
\end{abstract}

Keywords: Mercy, compassion, blind runner, Special Olympics, mutual aid “Lord, have mercy on me, a sinner” prays the tax collector in Jesus’ parable (Lk. 18:13). How often, one wonders, is this prayer heard among the athletes who sometimes gather before or after sporting events these days? No doubt other edifying prayers are uttered; that the game would be played in a sportsperson-like manner, to perform to the best of one's ability, to avoid injury or perhaps for perseverance in the face of setbacks. In this paper I will suggest that if we wish to think about such acts in the context of sport in substantively Christian terms, we will need to measure all such prayers against that of the repentant sinner of Jesus' parable. To call for divine mercy is the engine of genuine human compassion in every domain of human life, including sporting activity. 
The main proposal of the paper is that if Christians understand their engagement in sporting activities in abstraction from their responsibility to pray for and await God's own merciful action, they will inevitably conceive themselves as duty bound to be good sports. They will understand Christianity as equivalent to a moral system primarily aiming to enjoin merely human expressions of generosity and compassion. The limits of such accounts of compassion in the context of sporting activity become much more obvious when we try to apply them to the most arresting aspects of contemporary sporting activity. In a time during which so many sectors of the sporting world have become so blatantly beholden to the quest for fame, fortune and victory, it is important to recover a sense of the importance of mercy, compassion and humility in shaping engagement in sporting activity— both for those with and without disabilities.

My interest in recovering a genuinely Christian and theological language of compassion is primarily a tactical move. Among modern westerners, believers and unbelievers alike, the dominant uses of the language of compassion have been severed from any account of divine mercy. The most common deployments of the terminology of mercy or compassion assume that acts that are worthy of this label are best understood as expressions of an anthropologically universal urge, an inherited or hard-wired tendency toward concern for members of our herd inherited by the mechanisms of Darwinian natural selection. A starting presumption of this paper is that when Christians begin thinking compassion from this starting point they relegate themselves to providing motivational speeches so that people will actually go out and be compassionate in the terms that have already been set by these entirely this-worldly conceptual parameters. Sometimes when Christianity is conceived as an ideology for motivating people to "do the right thing" it becomes even more theologically problematic when the human acts of mercy and feelings of compassion are elevated to quasi-holy acts by theologies that urge 
Christians to action with language that suggests that we are God's arms and legs—and that if we do not act no one will. This conceptualization usually culminates in an exhortation to activism because "It’s up to us!"- and then to burnout, humans being creatures with limits (WiggStevenson 2013).

My suggestion is that if we do not begin again from the very start in thinking theologically about the what we mean when we say that some human act displays mercy or compassion, we will be consigned to this secular and immanent logic in a way that will obscure the most powerful exemplifications of mercy and compassion in sport. We will be rendered wordless in the face of the most profound sporting moments, much as were the journalists covering the 2016 Rio Olympics, who struggled all too evidently to find words for the "exceptional" act of one Olympian stopping to help another fallen runner. The New Zealander Nikki Hamblin and American Abbey D’Agostino were awarded the International Fair Play Committee Award after both fell during a 5,000 meter running event but subsequently helped one another to cross the finish line. Having only been awarded 18 times in the history of the games, the confusion among commentators about the existence of the award and how to describe it is perhaps unsurprising. We are not used to seeing such acts of mercy at the Olympics. And not only are acts of mercy and compassion almost invisible at the Olympics, there also seems to be a decidedly narrow account of what counts as mercy and compassion at work. Not only has the award been given very few times in the history of the modern Olympics, it this was only the second time the award has been given to a woman. In at least one commentator's view, this should cause us to think again about the gender assumptions that constitute modern ideals of "sportsmanship", assumptions that obscure the regularity with which female competitors come to one another's aid even when this does not advance their competitive advantage (Mahdawi 2016). We are in 
desperate need of thinking again about the place of compassion in modern sports, and in asking what we mean when we invoke the idea.

In this paper I retrieve a theological account of mercy that does not start by asking about human acts but begins by asking about the character of God's mercy and compassion toward humans. The basic constructive proposal I will defend is that, theologically understood, human beings are best understood as being paradigmatically merciful when they are understood as enacting a response to divine mercy, undertaking acts of mercy in God's name. I will suggest that this premise has been a deeply imbedded and practically significant strand of the Christian account of the intersection of these themes emphasizes.

The proposal that Christian disciples be understood as nothing more than responders to the working of divine mercy is an attempt to preserve the centrality of the biblical insistence that, in the final analysis, it is always God's mercy that protects and rescues human life. Because it flows from God, divine mercy is a reality that precedes our own acts and will be reaching out to those in need whether or not we respond to it. The God depicted in the Christian scriptures continually promises to uphold and give justice to those fragile human lives that everyone else has forgotten (Ps. 31:9, 40:11, 130:2, 145:9; Is. 30:18; Mic. 7:18; Rom. 9:15-16, 12:1). Because God alone can be trusted never to forget those who need mercy, all human acts of mercy must be understood not as "inventing” but following after God's own breaking into world occurrence on behalf of the distressed, as the German word for “discipleship” emphasizes: Nachfolge. This German term for discipleship highlights an understanding of the Christian life that recognizes this priority of divine mercy, and positions human faith as literally a following after ("folgen"=follow, "nach”=“after" or "in accord with”) the working of a merciful God whose action must precede and orient our own if we are truly to become this God's followers. 
I will develop my argument by exploring three linked ideas. The first begins from a criticism: today Christians and non-Christians alike speak about acts of mercy and compassion in a nontheological manner—as something like heartfelt good deeds that people extend each other. My first task, then, is to suggest why this is theologically inadequate, and why that inadequacy affects not only how we understand the notion but also shapes and forms the acts of compassion and mercy we understand ourselves to be enacting toward others. My second interest is in highlighting the bodily nature of human acts of compassion. Divine mercy can be conveyed through human bodies to remake and enliven both the body of the one who enacts mercy and its recipient. This seems especially interesting in the contexts of discussions of sport that so often turn on the training and remaking of the human body. How does being merciful, compassionate and humble reshape our bodies, and in what ways does this reshaping reposition how we might approach sporting activity? In a final movement I will draw these themes together with an example of the healing role of sporting activity in the life of the physically and mentally handicapped runner John Hughes. John’s story, I will suggest, offers us a worked example of how God's mercy can flow through human bodies in the context of sporting activities. It thus offers a politically potent challenge to the dominant ideological construction of sport today in which flawless athletic beauty, agonistic competition, and financial success have become such supreme values that simple acts of inter-competitive compassion and mercy leave us at a loss for words.

\section{Bodies as invitations to mercy}

It is true that human acts of love and charity toward other human being are sometimes called "works of mercy," most prominently in the Roman Catholic tradition. But as the story of Jesus'

healing of the paralyzed man emphasizes (Mark 2:1-12), this language can all too easily obscure 
an important distinction between things that God alone can do (to forgive sins) and what humans do (to attend to the needs of other people). Though divine mercy seems to have been linked in the Christian tradition with human acts of care or compassion, today this seems to us more of a puzzle than an obvious truth. In what way does human compassion relate to God's mercy?

What seems sociologically undeniable is that from the very beginning Christianity as a movement displayed a marked investment in caring for the outsider and the sufferer—an investment that has come deeply to shape the institutions of the modern west. In the ancient Greek and Roman worlds, for instance, lepers were shunned as those cursed by the gods, disowned by their families and banned from the city, but by the medieval period lepers are presumed by all to have the right to come into the heart of the city to participate in worship, as testified by late-medieval buildings such as St. Michael's Church in Zwolle, Netherlands, $\left(15^{\text {th }}\right.$ c.), with its "leper's chapel”. This church, in the very heart of the city and its marketplace, has a room on its side designed so that lepers, if not allowed to enter the nave with the congregation, could still be present for the mass, see the main altar, and receive communion through a barred window.

This example provokes us to consider how western civilization traversed the vast moral distance between the characteristic assumptions about the place of lepers in ancient Greek and Roman societies to arrive at the relatively less brutal forms of marginalization of people like sufferers of leprosy that we see in medieval Christendom. Whatever criticisms we rightly level at the medieval settlement, the important thing to note is the trajectory of the moral development, because it is one that leads directly to our world in which it would be unthinkable to say that any human being should be cast out of human society (at least in principle, if not in practice). The salient factor introduced by Christianity, I want to suggest, is the moral valorization of the 
human lives that had been labeled worthless or even threatening in the immediately preceding European cultures.

Such a marked change in the ethos of the Occident emerged out of a steady stream of countercultural acts of hospitality from the Christians of the first four Christian centuries. While the New Testament was still being written, we have evidence that Christians rejected common practices of abortion (Didache) and began to rescue and adopt babies abandoned to exposure. Already by the second century the church in Rome had become the largest supplier of food to the poor. The movement spread rapidly in no little part because such acts of hospitality were accompanied by sermons denouncing in the strongest theological language the shunning of some human beings as sub-human. One of the most famous sermons of this variety was the fourth century sermon of Gregory of Nyssa, who deployed a wide array of rhetorical argumentation to enjoin Christians to recognizing that shunning lepers represented not only a great slight against them, but also against God (Gregory of Nyssa, 2001). Nor was the sermon mere words. Gregory, alongside Basil the Great birthed the first monastic institution that offered to care for the sick and poor. It was an innovation that was to set in motion a new view of medical care that was no longer provided only for wealthy citizens, but to all in need. In short, many of what we think of as the most compassionate moral sensibilities of the modern west can be traced back to the most characteristic moral emphases held by Christians of the earliest Christian era (Miller 1997; Caspary 2012). This only deepens the puzzle of compassion, however, if we can no longer precisely articulate how a Christian understanding of mercy is related to such world-changing activities on behalf of outsiders.

One way to read the strong interest in reconnecting contemporary ideas about bodiliness with the idea of divine mercy that is evident at the beginning of the discipline of Christian disability 
theology is as a late echo and rediscovery of this connection that had been so potent in spreading Christianity in the first place. “The corporeal is for people with disabilities the most real,” wrote the pioneer of the field of disability theology, Nancy Eisland. She insisted that disabled people had to resist all disembodying trajectories in modern Christianity. Instead, taught by their own unwieldy bodies, disabled theologians are more able to, “attend to the kinesis of knowledge. That is, we become keenly aware that our physical selves determine our perceptions of the social and physical world” (Eisland 1994). The Christian God, she therefore insisted, helps us to reconceive the ways we have thought about disabled bodies in being a picture of a God who has suffered every bit as broken a body as the physically impaired.

Given this important insight, Nancy Eisland thinks it is highly unfortunate that the real experience of disabled bodies has been devalued by the narratives of heroic overcoming and bravery in the face of pain and physical and mental challenges that are so quickly applied to people with disabilities, especially those who are vigorous and athletic. As the extreme sportswoman and paraplegic Karen Darke has observed, it is very revealing how often she has heard the lines, “you're an inspiration,” or that you are, “so brave and positive about everything”. The regularity with which people made such comments to her enabled her to realize that such comments sprung from the values of "a society conditioned to value strength. A society that values “putting on a brave face” and coping” (Darke 2006). Darke’s story provides a detailed illustration of how difficult and important it is for sportspeople with impairments to be rescued from this valorization of strength and the internalized versions of this imperative they carry within them.

Eisland counters these dominant narratives by telling the story of Nancy Mairs, whose slow succumbing to muscular sclerosis had the effect of training her to "live as a body" (Eisland 
1994). As her body slowly surrendered the capacities it once had it progressively claimed ever more of her attention. This growing claim by her body inexorably remade her picture of herself. As her own body made its claim on her identity Mairs simultaneously found herself being opened to the claims being made on her through other's bodies, whose bodily affliction and need she began to perceive for the very first time. This awakening, Eisland points out, was at the same time a religious conversion, at the heart of which lay Mairs' awareness of her own need for mercy. As she put it in her own words,

I cannot patronize the poor. I am one of the poor. Currently my poverty isn’t economic, though it may one day be that as well, but its effects are similar. I must be not only the agent but the object of the works of mercy. I must discipline myself to accept and welcome other's care. I wish I could tell you that I'm doing a terrific job of it, that I'm just the sweetest, humblest little woman you've ever met, but I can't. All I can say is that, in learning to give whenever I can and receive care whenever I must, I've grown more attentive to the personal dimension of the works of mercy (Eisland 1994).

In this passage we see the traces of the older Christian tradition of the works of mercy with its emphasis on humility in the sheer bodiliness of the tasks both of offering and welcoming care for other bodies, as well as the discipline required to embrace it. Eisland's own stated reason for telling Mairs' story is its illustration that religious conversion into a life of receiving and giving mercy is a bodily activity. I have indicated why this is resonant with the compassionate hospitality characteristic of the earliest Christian centuries. I want to push beyond this emphasis on the awareness of embodiment that disability brings by suggesting that works of mercy become most fully intelligible when understood as responses to the primacy of the divine working being incorporated, bodily, into the lives of human beings. 


\section{Theologizing compassion}

This proposal to push beyond the terminus of Eisland's account at this crucial point is by no means novel, but rather is a recovery of a longstanding Christian ideal. The emphasis on the primacy of God's mercy and compassion in catalyzing and giving direction to human works of mercy was recovered and reconfigured in interesting ways during the Reformation period. The guiding assumption of this recovery was that God's determination to show mercy to fallen humanity, luminously on display in the Old Testament in his perseverant love for Israel, is glossed in the New Testament with the name Jesus Christ.

Like Eisland, the contemporary theologian Craig Keen reminds us that this starting point for thinking about human mercy is one that begins from a broken body. The Christian story that makes this body intelligible "is such a revolutionary story, precisely because it tells of his wounded flesh, his dead body, vis., that it was not left to rot on Easter Sunday, but immersed in a 'life' quite different from the life that comes and goes, the life analyzed by biochemists and insurance companies” (Keen, 2013). God’s compassion on human beings is more properly called mercy because its essence is the work of rescuing those in need. "Whatever else we might insist that the little three-letter word means, "God” resounds particularly well when-from under the heel of the beast, pressed down as beasts always are by the weight of their provisions for a negotiable future-prayers for salvation tear out of the bellies and throats of "expendables"” Keen continues (Keen, 2013). What is their prayer? “God, Creator of Israel and of the world, save your people!” (cf. Rev 19:1 and 20:9, Is. 43). Only when we become clear about the founding nature of divine compassion in establishing justice and rescuing creatures are we positioned to call the moment in which we become aware that God has mercy on this specific 
creature and in this specific life-giving way an act of compassion, at least if we want to understand acts of compassion Christianly.

Having been grounded in an act of divine mercy, this more robustly theological account of compassion allows a more diverse set of behaviors to be considered legitimate forms of suffering with others, as the Latin com-passio emphasizes ("passio” being the root of the English "passion” as in "suffering” and "com” being "with” in the sense of "joining in”). All this suggests a new focus of the question of human issue. The central problematic for a theological account of mercy, disability, and sport is how to understand our eyes being opened so that we can act under and within God's mercy. This formulation also reorganizes our account of what is going on when humans are ignoring God's merciful rule and its eschatological overturning of the regimes of this aeon which ground our non-merciful routines and seeing. To put matters this way suggests that mercilessness is a rejection of God, and so is best understood as an effect of the idolization of a power or value that makes being merciful look pitiable, weak, or counterproductive. This foregrounding of eschatological expectation and human engagement in the process of divine rescue ought not to be understood as an insistence that only Christians can be merciful and compassionate. Though I cannot develop them here, there are good Christian reasons to insist that unbelievers too can respond appropriately to real creaturely goods and so can serve God’s own mercy to creatures (Schwanke 2014).

For Martin Luther at least, the Christian story of God’s works of mercy begins with creation, a work that is a mercy on all creatures in allowing them to exist, and providing them with all good things. This Old Testament picture of a broad and deep divine mercy deeply inflects in turn how Luther understands the work of Christ. He saw the story of the world as shot through with divine acts of mercy, beginning not only with the first creation from nothing, but also in the Garden of 
Eden when God offers the newly fallen humans the so called proto-evangelion, the promise that God wills eventually to defeat the tempter, the enemy and destroyer of humanity. In the curse levied at the serpent in Genesis 3:15 God says, "I will put enmity between you and the woman, and between your offspring and hers; he will strike your head, and you will strike his heel.” (NRSV). Luther suggests that these words are pronounced not only as a judgment on the serpent, but also in order to comfort Adam and Eve by giving them hope that God will defeat the sin which has so gravely wounded them. He continues, "Here grace and mercy [misericordia] begin to shine forth from the midst of the wrath which sin and disobedience aroused. Here in the midst of most serious threats the Father reveals His heart; this is not a father who is so angry that he would turn out his son because of his sin, but one who points to a deliverance, indeed one who promises victory against the enemy that deceived and conquered human nature” (Luther, 1958).

It is clear that for Luther the grammar of "divine mercy" and "Jesus Christ" are reciprocally defining, and have a messianic logic, because Luther is primarily concerned not with God's character as merciful in the abstract, but with manifestations of divine mercy. He develops a link between central acts of God's merciful deliverance, such as Israel's rescue from Egypt (Ex. 3) and the ethos on display in Jesus' life, which grounds his command to "be merciful as the Father is merciful” (Lk. 6:36). The logic of this approach suggests that the dominical command to be merciful "as" the Father is merciful is not levying an ethical demand nor proposing Christian acts of imitative mercy. Instead, humans are beings who can only properly act as those claimed by and for God's mercy, having been "created in Christ Jesus for good works, which God prepared beforehand to be our way of life" (Eph. 2:10).

Luther's reading of mercy in the Old Testament can thus not be separated from the work of Jesus Christ, which lay at the core of his great discovery of God's work of justification. 
...a human being, rather than his works, must be just, and that he is accepted by God without any works, solely through grace, which faith believes and apprehends. Nor does faith, as a work, make just, but it makes just because it apprehends the mercy which is offered in Christ. The true church walks in this trust in God's mercy, together with a humble confession of its sins and unworthiness, which hopes that God will grant His pardon through Christ. ...the works which follow are evidences, as it were, of this faith; they please God, not simply on their own account but because of or because of the believing person (Luther 1958, emphasis added).

In short for Luther the term "mercy" is grounded in the doctrine of God, and specifically, in an account of the economy of salvation —-the working of God to rescue and uphold those who were in need and perishing.

This theme was recovered and elaborated in modern theology by Karl Barth, most famously in $\S 30$ of his Church Dogmatics (Barth 1957). Barth took up and elaborated Luther’s emphasis that to speak human acts of mercy and compassion must first and continually be a speaking about the activity of God rather than a principle of moral Christian action. His point was that we end up losing the connection of human and divine mercy if we lose the biblical emphasis within the biblical grammar of the mercy of God being conceived as a stream of divine activity that flows from God to shape and lend beauty and wholeness to the activity of human lives. Amidst this stream of divine care for human beings human acts are properly understood only as merciful by proxy. As Barth’s student and conversation partner Dietrich Bonhoeffer pointed out, this sets up all ascriptions of human mercy as eschatological recognitions of divine blessing, as Jesus apparently suggests in the Sermon on the Mount "Blessed are the merciful, for they will be shown mercy” (Mt. 5:7). In his comments on this verse Bonhoeffer emphasized that to become a 
Christian disciple is to be willing to give up any honor that might be bestowed by other humans out of a desire to serve God's mercy. To be a disciple is by definition to "know only one dignity and honor, the mercy of their Lord, which is their only source of life.” The example of mercy Christian disciples are following is one characterized by lack of shame in loving disciples who were far from perfect, and one that was so to people that he bore their shame to the point of embracing the utter shaming of a public execution. The works of mercy and compassion that should characterize the Christian, therefore, follow in the train of a God whose most paradigmatic act of mercy was characterized by a total lack of shame at rescuing humanity by suffering being "the biggest loser" on the cross.

This is the mercy of Jesus, from which those who follow him wish to live, the mercy of the crucified one. This mercy lets them all forget their own honor and dignity and seek only the company of sinners. If shame now falls on them, they still are blessed. ... Blessed are the merciful, for they have the merciful one as their Lord (Bonhoeffer 2001).

With this line of interpretation of Christian discipleship Bonhoeffer was developing not only Luther's emphasis on the priority of divine mercy but also Barth's elaboration of how this priority wholly resituates the Christian's understand of the role of their own action in the world. The divine mercy displayed toward all humanity in their wretchedness and need in the cross of Jesus Christ makes all who follow this good responsible to all those who are in need, who suffer wrong, who are poor and wretched in the eyes of the world. In other's need for compassion the Christian disciple should see icons of our own need, to which God's merciful compassion reached out in Jesus Christ (Barth 1957)—in the same way that Nancy Mairs learned to see the very bodily needs of others as her body taught her that she too was needy. 
I trust that it has now become clear that there are well-developed theological resources that can give us purchase on our opening puzzle about the relation of God's self-determination to extend mercy to human beings to and the acts of mercy and compassion humans might enact. When humans hear of and respond to God's promise to be merciful, and receive this mercy in the work we call faith, they begin to look for an so open themselves to collaborate with God's work of rescuing those in need. It is in this way that humans are directed into the ways of justice and peace. We are now in the position to explicitly state that God's works of mercy are ones that most regularly seek to remake our world not directly, but through acts of compassion for the neighbor.

\section{The appearance of divine mercy in the scenes of human life}

If, as Luther firmly believed, God, "has so richly given us the signs of His grace that we can have them before our doors, yes, even in our houses and in our beds” (Luther 1958), we will need to explore what it means to experience events in our world as "manifestations of mercy". These must be apprehended in real time, and so "heard" as God's articulate works, to use the biblical idiom. "Hearing" will need to be understood as going beyond the auditory organs of sensation to indicate a bodily receptivity to the impingement of something outside of us, a happening in the material creation (a view, how counterintuitive it might seem to some, that has been held by a wide variety of religious and non-religious adherents in modernity (Schmidt 2000)).

The well-known parable of the Good Samaritan pivots on the line, "when he saw him, he was moved in his bowels” and ends, significantly for our purposes, by summarizing the response to this inner movement as a "showing of mercy". In the parable, I want to suggest, Jesus is concretizing in a very material way how we should understand the descent and advent of divine 
mercy. A Hebraism, splanchnizesthai- “to be deeply moved” as in "deeply in the bowels", appears at several crucial points in the gospels, offering us a Christological point of connection between the claim of divine mercy and the human body. A picture emerges of a depth of bodily connection between human beings that is evidence of a heightened of bodily conaesthetic sense. We saw Eisland labelling this the "kinesis of knowledge". We also saw how she understood this knowledge one of the fundamental gifts of physical disability, in that losing bodily function heightens our awareness of this aspect of being human. I now want to ask what it means that the Messiah who has travelled into the far country describes the movement of divine mercy as linked to being "moved in his bowels" toward humans (See Mk 1:41, 8:2 and par., Mt. 9:36, 18:27, 20:34; Lk. 7:13; 10:33. English translations often obscure this Hebraism with the translation "pity”).

As I have already hinted, if this odd biblical idiom is going to become intelligible to us today, we will need to begin by jettisoning the view popular among modern Christians that "hearing the word of the Lord" is something that happens only to prophets on mountains or maybe every once in a while through a sermon. Jesus seems to conceive the responsivity of humans to the divine claim is a rather more mundane and bodily affair. This also suggests that we need to reconceive the idea of the "word" more broadly, as a divine claiming that is "heard" whenever it is perceived by a human being.

If it is true, as Jesus taught, that human beings are creatures whose true sustenance is the hearing of the word of the Lord (Mt. 4:4, Deut. 8:3), then here "hearing" must be understood as a metaphorical description of something like a communicative sensation. At this point the philosopher Michel Serres can help us give content to this counterintuitive but this theologically important point by drawing our attention to the biophysical reality that touch is the fundament of 
all human sensation. Comparing the body to a tent, he describes all the senses as sensitive veils which are designed to be impacted by perturbations in the world. Even though our tongue and eyes and ears are not actually entered by the things we sense, they are configured in such a way that something from the world outside the body can travel through them, making itself "heard" on the inside of the body without penetrating the integrity of that body. Thus "Touch ensures that what is closed has an opening (Serres 2008, cf. Linden, 2015).

Serres deploys the term "conaesthesia" to name the inner world of impressions we have of the body's relation to the world, that that arises from these organic sensations, combined with one's awareness of one's internal bodily state, such as the feeling of health, vigor, or lethargy. With this account Serres seeks to overcome the dualism so characteristic of modern thinking based as it is on the famous claim of Descartes that the "self"- the "I"-lies within the mind and is other than the body. For our purposes it is worth noting that Descartes' pivotal moment of conceptual clarity about what it means to be a "self" came during a dream while dozing in an overheated room, whereas Serres comes to terms with his most fundamental account of the "I" while undergoing a fiery shipwreck. The threat of bodily death and the bodily resistance he felt to it, by the same mechanisms as Nancy Mairs recognized her loss of bodily functioning, revealed to Serres something essential about what it actually is to be a human being, and to have a "self". The individual "I" is, he concluded,

...something everyone knows, unemotionally and as a matter of fact. You only have to pass through a small opening, a blocked corridor, to swing over a handrail or on a balcony high enough to provoke vertigo, for the body to become more alert. The body knows by itself how to say I. It knows to what extent I am on this side of the bar, and when I am outside. It judges deviations from normal balance, immediately regulates them 
and knows just how far to go, or not go. Coenesthesia says I by itself. ...This internal sense proclaims, calls announces, sometimes howls the I like a wounded animal. This common sense apportions the body better than anything else in the whole world (Serres 2008).

In reflecting on his life- and identity-altering brush with death Serres thus discovered his precise points of agreement and disagreement with the modern account of selfhood. "Descartes was right to say that the soul touches the body at a particular point, but he was wrong to locate it in the pineal gland. It hovers around the region of the solar plexus”. Why so? Because, "the soul resides at the point where the I is decided” (Serres 2008).

If for Serres the "I" "hovers around the region of the solar plexus," we have moved some way from the Cartesian "I" that resides in the mind and have almost reached the compassionate "I" that Jesus taught resides in the bowels. My suggestion is that in Jesus Christ we witness a "self", understood as an embodied identity, whose dedication to meeting and serving God's mercy toward human beings in need of rescue emerges from the innermost parts of the viscera. Read this way, Jesus both model and teacher of a responsiveness to God that is enacted in relationships with others. The "suffering and sin and abandonment and peril of these men not merely went to the heart of Jesus but right into His, into Himself, so that their whole plight was now his own, and as such He saw and suffered it far more keenly than they did,” observes Barth. Jesus’s suffering the plight of the needy other, in addition, because it is an internalization of the cause and success of the other person into his own inner life can never remain merely an affective disturbance but must be expressed in practical assistance. Thus, concludes Barth, "The verb [splanchnizesthai] obviously refers to the action of Jesus, but it tells us that this has an inward source and is the movement of the whole man Jesus" (Barth, 1960). Jesus' whole being is 
defined by his utter commitment to specific concrete humans, and reveals itself specifically and concretely in the fibers of his body.

In Jesus Christ we are shown the maximal embodiment of human acts of compassion at the point of their birthing within God's act of mercy. Though this mercy is only fully embodied in Jesus, in his parables he nevertheless insists that human works that are pleasing to God will act in the name of this same divine mercy. It is these considerations that led the theologian and activist Ivan Illich to read Jesus' parable as revealing that the dis-ease that the Samaritan perceived in the body of the wounded man "was a gift from the other” (Illich 2005). As our stomachs clench and hearts race in self-concern when we approach a railing above a high precipice, or as we reflexively flinch to avoid a projectile that we do not consciously see, the Samaritan's body, like Jesus', reacted immediately and spontaneously to the presence of a suffering human upon whom God has mercy. Divine mercy in this way becomes contagious, and in so doing, exposes the contours of the brokenness of particular social locations which cause creatures to suffer. Jesus Christ comes and claims us as he was claimed by us, through bodily, fleshly senses, in the face of the reality that this bodily form of knowing has been radically undermined in an age in which we have come to believe that in order truly to know a body it must be rationally objectified, even our own.

In Illich's reading (which I have framed by linking it to the wider Christian tradition as appropriated in Luther's thought) Jesus both enacts and teaches an ethos of human responsivity to God's merciful desire to rescue broken creatures. The parable of the Good Samaritan is on this view not intended as a display an exemplary act of charity: "What the beaten-up Jew's presence evokes in the Samaritan's belly is a response which is not [in the first instance] purposeful but gratuitous and good... Gratuity is not something which can flow out of me unless 
it is opened and challenged by you” (Illich 2005). Because mercy is the fundamental gratuitous act of a loving God, a God who is both over and above the whole of creation is at the same time one who ties us to it through the presence of the neighbor.

By welcoming the divine mercy poured out on us we learn to perceive it reaching out toward the lives and need of our neighbors. To receive divine mercy is thus a training in recognizing our neighbors as subjects of God's merciful love, which, as we saw in Mair's example, is to become attuned to the physical concreteness of the claim they make on us. The unnaturalness of this form of perception is indicated by the necessity that it be paired with repentance of our lack of mercy, as well as followed up with a disciplined resistance to the idolatries that seek to reclaim us for other priorities and values. This creature in my presence is thus a divine emblem of God's grace as well as a concrete invitation to embrace the divine mercy and in doing so to discover what it means to love the God who is all in all.

We are to love the God who simultaneously loves justice and whose steadfast love flows throughout the world (Ps. 33:5), but only, the biblical traditions tell us, in and with the neighbor (Lev. 19). We thus need the neighbor and their need to activate our bodily compassion, as the medium through which our sense of fellow feeling can be developed, through whom we will be embedded in our place. Illich concludes, “God didn't become a man, he became flesh. I believe, as I hope you do, in a God who is enfleshed, and who has given the Samaritan, as a being drowned in carnality, the possibility of creating a relationship by which an unknown, chance encounter becomes for him the reason for his existence, as he becomes the reason for the other's survival—not just in a physical sense, but a deeper sense, as a human being” (Illich 2005). What Israel and the church confess and hand on has been learned not by grasping the beatific vision of the One, but in becoming aware that the many vectors of the natural world and the economy of 
God's action are tangible in every unique person and place. Christians do not worship a universal God knowable apart from his presence and action in creaturely locales, supremely in the life and death of Jesus Christ. And has Barth noted, this directly situates our understanding of the definitional context of Christian mercy. When Christians confess that God is merciful, "it is not even remotely possible to demonstrate this as a logically deducible truth.” The Christian can do nothing more than acknowledge it as a reality by living within this mercy. "What else can we produce as a proof of this confession except the fact that God has given Himself to be known by us as merciful in the name of Jesus Christ?” (Barth 1957)

It turns out that what is essential to a genuinely Christian and theological account of mercy is a formed perception of this neighbor as clothed by the divine promise of a God whose will is to enact mercy. This formed perception is born in the receipt of divine mercy, a reception shaped by the recognition of the form of God's mercy as one which is determined to rescue needy human life, in which we are included, and which does not hesitate to give up fame or glory to extend a helping hand.

\section{A merciful sports}

Sport is a bodily activity, which makes it a particularly useful arena in which to seek out examples of enacted mercy. If God's mercy in Christ is one that is not afraid to give up honor in order to rescue those crying out in need, if we can discover examples of mercy at work, we should be able to see more clearly the ways that works of mercy enrich human lives, whether disabled or not, and how such acts of mercy can challenge not only the dominant values of contemporary sport, but of modern society as a whole. A well-known observation of Jean Vanier's hints at the complex challenge all this presents to sports as we know it today. 
There is a beautiful story of a young man with a disability who wanted to win the Special Olympics; he got to the hundred meter race and was running like crazy to get the gold medal. One of the others running with him slipped and fell; he turned round and picked him up and they ran across the finishing line together last. Are we prepared to sacrifice the prize for solidarity? It's a big question. Do we want to be in solidarity with others? ... We have to look at the poorest and the weakest. They have a message to give us (Whitney-Brown 2008).

Observations like these have led some disability theologians to suggest that when the Apostle Paul compares the Christian life with a sporting event, precisely because he is talking about Christian life that follows in the wake of divine mercy, "Paul's model athlete is less the champion of the Isthmian Games [Olympic-style events that took place regularly in first century Corinth] than today’s Special Olympian” (Yong 2015). Because Paul understands all Christians as running and training to win the approval of Jesus Christ and to participate in his victory, such running needs no losers because it "looks out for the welfare and success of all, with those who appear to be the least able in engaging the task being the most indispensable and honored" (Yong 2015). It is a humble sportsmanship that is constantly prepared to have its sporting ideals interrupted in being reliant on the work of the Spirit whose gifts are of peace, faithfulness, patience and gentleness. As theologians interested in sport have pointed out, this is not a disembodied ideal, perhaps of resisting pridefulness in the heart or being deferential to others, but is a much thicker day to day practice, a humility that epitomized Jesus’s character: "learn from me, for I am gentle and humble in heart” (Mt. 11:29) Nick Watson and John White observe. In him we see what Paul calls the fruits of the spirit, "love, joy, peace, patience, kindness, 
goodness, faithfulness, gentleness and self-control,” (Gal. 5:22-25). It is an example that presents a substantial challenge to contemporary sportspeople, Watson and White continue.

"How do you prepare for an agonistic [contest] event for months by rigorous training, defeat a worthy opponent in public contest for a worldly prize and glory, and still be an example of "gentleness" and "meekness," to name only a couple of the famous "fruit”? Is this also as difficult to do as a camel going through the "eye of a needle"? To make matters more complicated, what if the winning athlete in question makes a quarter of a billion dollars per decade?” (Watson \& White 2012; quoting Higgs \& Braswell 2004)

Without a thick theological account of mercy it is hard to imagine humility as anything other than a resistance to bragging about one’s success. In short, without mercy there cannot be any real humility in sport, which, at best, will be characterized by magnanimous winners.

We live today in a world in which our paradigmatic exemplars of sporting excellence are constantly surrounded by suspicions of doping and other forms of cheating, are very often proudly obsessed with winning and achieving high pay, and must carry on under the bright lights of an overweening celebrity culture. As the doping scandals at the Rio Paralympics revealed, having a disability provides no immunity to these temptations (Haigh 2016; Gibson 2016). The power and destructiveness of these forces has led Nick Watson to see in them a "tower of Babel of modern sport”. Like Eisland, his response to the manifest injustice of this majority culture is to offer the a story as a counter-narrative to the victory cult that that is so dominant in contemporary sporting cultures, an example that speaks far more eloquently than any theoretical account. 
John and Sylvia Hughes first fostered and then adopted James, a young man who had been raised in care homes since he had been an infant. James was born without eyes and had learning difficulties so severe that he has never developed much speech. In 1987 John and Sylvia, who already had five children, took in 14 year old James as a foster child, later adopting him. A lifetime of living in care homes had devastated James’ personality: the various degrees of neglect, isolation and rejection he had experienced left him fearful of intimacy, self-harming, prone to violent outbursts and unable to walk more than a hundred yards outside of the home without breaking into defensive screams and curling up in a ball on the ground. This was a young man in need of rescue in the most literal sense. After many years of training, John and James have now run together 41 marathons and 77 half marathons. James lightly touches his father's arm from behind as they run and John sings to provide orientation for James when approaching a difficult or curving stretch of road.

As devout Christians, John and Sylvia understand their call to embrace James to be an expression of God's mercy for James. Through a shared life in which sporting activity has played a prominent place, they believe they have come to see in concrete detail the operation of God's mercy in healing James' brokenness and suffering. They understand this healing to be both an expression of their love for him and a witness to the work of a God in whose sight every human is of infinite worth. The story of James turns out to be a story that John understands in terms of James receiving the divine mercy that God shows to him as received bodily by his adoptive parents. Out of the love John knew God had for James, a broken and dependent adopted son had to learn to accept the grace, love and guidance of his earthly, and through him his heavenly Father. John tells the story this way. 
... when we first started, we were just walking but his confidence grew over the months [and then] years. We tried to innovate and one of the innovation was to hold his two hands on a hill and pull him down. Then I started turning backwards and he had no concept, with being blind, of running. Like if a child goes to the baths and sees other children making breast strokes...but being blind he hadn't got that concept of the world...it’s like if you get up in the night and there's no light on. Your steps are small. The inch becomes a cliff [laughter]. James's steps were small, so what I've done is make him make bigger strides. I used to grab hold of his trouser legs and lift his legs up and down to give him the movement. ...so it was those small things.

I was getting to know James and he was getting to know me and over a long period of time, my confidence in him and is confidence in himself and his ability were building up. We went from the foundations ... and then I said we'll put shorts on and we'll go and try jogging and many a time he'd throw himself on the floor screaming ... now after about a year our breakthrough came and he threw himself down on the floor and needless to say he'd get an audience straight away, looking at him screaming. ....and I said to him get up, get up for my sake and I knew I'd said the wrong bloody thing [laughter] ... holding him [James] and getting to his feet I said from this moment on your going to do it on your own ...He's screaming by the way all the time now and I'm holding him tight and we're standing nose to nose and I said "from this moment on you're going to do it on your own and one thing, I'm never going to leave you."

He had the ability to do it and with those slow beginnings ...from the initial 200 yards or so down the road, going across the road ... we were running for an hour as a jog and his first race we went to was a Liverpool race and it was called 'Give a Child a Chance'. 
That was a three mile race ... He did stop a bit in the three miles, but when he finished he was smiling so I knew it was something (Watson and Parker 2015).

This is no proof that my account of mercy and compassion is accurate. But it is an example of what sporting activity looks like when human beings understand what they are doing as part of the movement of divine mercy for those in need of rescue and a place where they can be at home. As Barth has pointed out, there is no more definitive proof than this of God's mercy. We can never say definitively that James heard the Lord's own love through John's promise that "I'm never going to leave you." What we can say for certain, though, is that these are words that the God of Abraham, Isaac and Jacob repeatedly uttered and followed through on by repeatedly picking them and their heirs up in their destitution and need. It is the stories of the divine words and works of mercy that invite us to see the story of the Hughes family as an example of how divine mercy both breaks into our world and gains its foothold by being received and handed on through acts of human compassion. It also suggests a configuration of sport standing as a hopefilled contradiction of an idolatrous majority culture of sport.

It is also, finally, a reminder that we must be trained to be ruthless competitors just as the members of developing nations had to be trained into the winner-takes-all competitive mind-set assumed in the modern developed world. Jules Boykoff has recently recalled the sorry tale of the first explicitly named Special Olympics. Staged alongside the 1904 Olympic Games in St. Louis, this first Special Olympics was conceived as an "anthropological exhibit" designed to display the athletic superiority of white westerners by pitting them against indigenous peoples from around the globe. In the end, Boykoff comments, "cultural differences wrecked the master plan. Instead of plunging through the finish-line ribbon, indigenous runners would wait for their colleagues or duck under the tape. As Parezo notes, “Cooperation was more important than 'victory'... waiting 
for friends was a sign of graciousness and a symbol of respect in many cultures” (Boykoff 2016, quoting Parezo, 2008). Such non-conformity was met with disqualification and was taken by the event organizers as obvious proof of white racial superiority. Such stories remind us of the hidden violence weaved into the deep fabric of the majority culture of modern sport which only occasionally reaches the more vulgar heights of vanity, the desire to crush or humiliate opponents, obsession with wealth and unhealthy body image. Such an idolatrous culture can claim even Paralympians like Oscar Pistorius, no less than the godlike figures of sport such as Lance Armstrong. But in faithfully fostering the prophetic existence of witnesses like the Hughes family, the God of mercy continues to open up important questions not only about disability, but about the ways we think about, watch and engage in sporting activity today.

Barth, K. (1957). Church Dogmatics II.1. G. W. Bromily \& T. F. Torrance (Eds.). Edinburgh: T\&T Clark.

Barth, K. (1960). Church Dogmatics III.2. G. W. Bromily \& T. F. Torrance (Eds.). Edinburgh: T\&T Clark.

Bonhoeffer, D. (2001). Discipleship, Dietrich Bonhoeffer Works, vol. 4. G. Kelly \& J. Godsey eds. Minneapolis: Fortress Press.

Boykoff, J. (2016). Power Games: A Political History of the Olympics. London: Verso.

Parezo, N. J. (2008). A 'Special Olympics': Testing Racial Strength and Endurance at the 1904 Louisiana Purchase Exhibition. In The 1904 Anthropology Days and Olympic Games: Sport, Race and American Imperialism. S. Brownell ed. Lincoln: University of Nebraska Press. 
Caspary, A. (2012). The Patristic Era: Early Christian Attitudes toward the Disfigured Outcast. In Disability in the Christian Tradition: A Reader. B. Brock \& J. Swinton eds. Grand Rapids: Eerdmans.

Darke, K. (2006). If You Fall. Winchester UK: O Books.

Eisland, N., (1994) The Disabled God: Toward a Liberatory Theology of Disability. Nashville: Abingdon.

Gibson, O. (2016). Paralympics show way on Russian doping to shame of IOC. The Guardian, 8 August.

Gregory of Nyssa (2001). "On the Love of the Poor 2: On the saying, 'Whoever Has Done It to One of These has Done It to Me.’” In S. R. Holman, The Hungry are Dying. Oxford: Oxford University Press, pp. 199-206.

Haigh, G. (2016). Russian crisis sheds light on political apathy at dark heart of Olympics. The Guardian, 21 July, Sport, 2.

Higgs, R. J. \& Braswell, M. C. (2004). An Unholy Alliance: The Sacred and Modern Sport. Macon GA: Mercer University Press.

Illich, I. (2005). Rivers North of the Future: The Testament of Ivan Illich as told to David Cayley. Toronto: Anansi.

Keen, C. (2013). After Crucifixion: The Promise of Theology. Eugene: Cascade.

Linden, D. J. (2015). Touch: The Science of Hand, Heart, and Mind. London: Viking. 
Luther, M. (1958) Lectures on Genesis, Luther's Works vol. 1, Lectures on Genesis chs 1-5. J. Pelikan ed. St. Louis: Concordia.

Mahdawi, A. (2016). Nikki Hamblin and Abbey D’Agostino: the sisterhood of sportswomanship still rules. The Guardian, 17 August 18.58 BST.

Miller, T. S. (1997). The Birth of the Hospital in the Byzantine Empire. Baltimore: Johns Hopkins University Press.

Schmidt, L. E. (2000). Hearing Things: Religion, Illusion and the American Enlightenment. Cambridge: Harvard University Press.

Schwanke, J. (2014) “Luther’s Theology of Creation”. In The Oxford Handbook of Martin Luther's Theology. R. Kolb, I. Dingel, and L. Batka eds. Oxford: Oxford University Press, 201211.

Serres, M. (2008). The Five Senses: A Philosophy of Mingled Bodies (I), M. Sankey and P. Cowley trans. London: Continuum International.

Watson, N. J. \& Parker, A. (2015). “Christianity, Sport and Disability: A Case Study of the Role of Long-Distance Running in the Life of a Father and his Son who is Congenitally Bind and has Profound Intellectual Disabilities”. In Sports, Religion and Disability. N. Watson \& A. Parker eds. London: Routledge.

Watson, N. J. \& White, J. (2012). “C. S. Lewis at the 2012 London Olympics: Reflections on Pride and Humility”. Practical Theology, 5.2.

Whitney-Brown, C. (2008). Jean Vanier: Essential Writings. Marynoll, NY: Orbis. 
Wigg-Stevenson, T. (2013). The World is Not Ours to Save: Finding the Freedom to do Good. Downer’s Grove: Intervarsity.

Yong, A. (2015). Running the (Special) Race: New (Pauline) perspectives on Disability and Theology Sport. In Sports, Religion and Disability. N. Watson \& A. Parker eds. London: Routledge. 